\title{
SMOKING BY PRIMARY SCHOOLCHILDREN PREVALENCE AND ASSOCIATED RESPIRATORY SYMPTOMS
}

\author{
BEULAH R. BEWLEY, T. HALIL AND A. H. SNAITH \\ Department of Clinical Epidemiology and Social Medicine, St. Thomas's Hospital Medical School, London SE1 and \\ County Health Department, Derbyshire
}

One of the earliest accounts of the effects of tobacco on young people appeared in 1606. In 'The Copy of a Letter written by E. D. Doctor of Physic to a Gentleman by whom it was Published', E. D. argued that tobacco was:

1. Not safe for youth

2. It shorteneth life

3. It breedeth many diseases

4. It breedeth melancholy

5. It hurteth the mind

6. It is ill for the smokers issue.

'.... to conclude. Since it is so hurtful and dangerous to youth I wish that it might have the pernicious nature expressed in the name and that it were as well known by the name of youth's bane as by the name of tobacco' (E. D., 1606).

Three and a half centuries were to pass before the use of epidemiological methods confirmed the statements that tobacco 'breedeth many diseases' and 'shorteneth life' (Royal College of Physicians, 1962).

A number of studies of adults have shown that respiratory disease is associated with cigarette smoking (Royal College of Physicians, 1971) and there is also increasing evidence that respiratory disease begins in childhood (Douglas and Waller, 1966; Colley and Reid, 1970; Holland, Halil, Bennett, and Elliott, 1969 a and b; Lunn, Knowelden, and Handyside, 1967; Lunn, Knowelden, and Roe, 1970). Holland and his colleagues, in their study of Kent secondary schoolchildren, demonstrated an association between cigarette smoking and respiratory symptoms. There has, however, been no large-scale study of smoking and health among younger children. The study described in this paper attempted to fill this gap. It aimed to investigate the prevalence of smoking by primary schoolchildren and to determine whether a relationship between smoking and respiratory symptoms appears at this early age.

\section{Study Population and Methods}

The study population consisted of the 8,682 children aged between 10 and $11 \frac{1}{2}$ years who were in their final year of primary school in the Administrative County of Derbyshire (excluding the Borough of Chesterfield). In March 1971 these children were asked to complete a self-administered questionnaire on their respiratory symptoms and smoking behaviour. The questionnaire was based on the Medical Research Council $(1960,1967)$ respiratory questionnaire. It was explained to the children by their teachers and was completed in the classroom Confidentiality was emphasized and the childre were assured that the information would not be revealed to their parents or to the school authoritieso Questionnaires were returned directly to the Depart:ment of Social Medicine, St. Thomas' Hospital in individual stamped addressed envelopes.

There were difficulties in deciding on smoking classifications since it was unlikely that children of this age would be smoking much. Finally, we defined a child who reported smoking at least one cigarette a week as a smoker; a child who had ever puffed or smoked a cigarette, but was not a smoker as defined, as an experimental smoker; and a child who had never smoked as a non-smoker.

We grouped the children as 'urban' or 'rural' according to the location of the school they attended (Derbyshire County Report). We were unable to group them according to area of residence since, for reasons of confidentiality, we did not obtain their home addresses.

\section{Results}

Seven thousand one hundred and fifteen children (3,636 boys and 3,479 girls) completed the questionnaire-a response rate of $82 \% ; 6.1 \%$ of children were absent from school on the day the questionnaire was administered and $11.9 \%$ did not respond. Of the latter, $10.7 \%$ did not complete questionnaires 
TABLE I

SMOKING HABITS AS REPORTED BY SCHOOLCHILDREN

\begin{tabular}{|c|c|c|c|c|c|c|}
\hline & \multicolumn{2}{|c|}{$\begin{array}{c}\text { Boys } \\
(3,636)\end{array}$} & \multicolumn{2}{|c|}{$\begin{array}{c}\text { Girls } \\
(3,479)\end{array}$} & \multicolumn{2}{|c|}{$\begin{array}{c}\text { Total } \\
(7,115)\end{array}$} \\
\hline & No. & $\%$ & No. & $\%$ & No. & $\%$ \\
\hline \multirow{2}{*}{$\begin{array}{l}\text { Non-smokers } \\
\text { Experimental } \\
\text { smokers } \\
\text { Smokers }\end{array}$} & 2,087 & $57 \cdot 4$ & 2,654 & $76 \cdot 3$ & 4,741 & $66 \cdot 6$ \\
\hline & $\begin{array}{r}1,294 \\
253\end{array}$ & $\begin{array}{r}35.6 \\
6.9\end{array}$ & $\begin{array}{r}732 \\
91\end{array}$ & $\begin{array}{r}21 \cdot 0 \\
2.6\end{array}$ & $\begin{array}{r}2,026 \\
344\end{array}$ & $\begin{array}{r}28.5 \\
4.8\end{array}$ \\
\hline \multirow{2}{*}{$\begin{array}{l}\begin{array}{l}\text { No. of cigarettes } \\
\text { smoked (per } \\
\text { day) by smokers }\end{array} \\
<1 \\
1 \text { or more } \\
\text { Amount not } \\
\text { known }\end{array}$} & $\begin{array}{r}192 \\
29\end{array}$ & $\begin{array}{l}75 \cdot 9 \\
11 \cdot 5\end{array}$ & $\begin{array}{r}76 \\
4\end{array}$ & $\begin{array}{r}83 \cdot 5 \\
4.4\end{array}$ & $\begin{array}{r}268 \\
33\end{array}$ & $\begin{array}{r}77.9 \\
9.6\end{array}$ \\
\hline & 32 & $12 \cdot 6$ & 11 & $12 \cdot 1$ & 43 & $12 \cdot 5$ \\
\hline Not known & 2 & 0.1 & 2 & 0.1 & 4 & 0.1 \\
\hline
\end{tabular}

because of refusals by head teachers or parents to allow them to take part in the study, and $1.2 \%$ failed to return completed forms.

\section{SMOKING}

Regular smoking was reported by $6.9 \%$ of the boys and $2.6 \%$ of the girls (Table I) and a higher proportion of boys experimented with cigarettes. Boys also smoked more cigarettes than girls; $11.5 \%$ of the boys who admitted smoking regularly smoked one or more cigarettes per day, compared with $4.4 \%$ of girls. Almost all the children who smoked one or more cigarettes a day reported smoking between one and two cigarettes. Only one girl and three boys said they smoked three or more a day. We found no significant differences between the smoking habits of children from urban or rural schools (Table II).

\section{RESPIRATORY SYMPTOMS}

The prevalence of respiratory symptoms is shown in Table III. Seven per cent of children reported a morning cough, $23 \%$ reported a cough at some time of the day or night and $4.5 \%$ reported that the cough lasted for three months or more. There was a
TABLE III

PREVALENCE OF REPORTED RESPIRATORY SYMPTOMS BY SCHOOLCHILDREN

\begin{tabular}{|c|c|c|c|c|c|c|c|}
\hline \multirow{3}{*}{\multicolumn{2}{|c|}{ Replies }} & \multicolumn{6}{|c|}{ Reported Symptoms } \\
\hline & & \multicolumn{2}{|c|}{$\underset{\text { Cough }}{\text { Morning }}$} & \multicolumn{2}{|c|}{$\begin{array}{l}\text { Cough during } \\
\text { Day or Night }\end{array}$} & \multicolumn{2}{|c|}{$\begin{array}{c}\text { Cough lasting } \\
3 \text { months or } \\
\text { more }\end{array}$} \\
\hline & & No. & $\%$ & No. & $\%$ & No. & $\%$ \\
\hline $\begin{array}{l}\text { Yes } \\
\text { No } \\
\text { Don't know } \\
\text { Not applicable }\end{array}$ & $\begin{array}{l}\cdots \\
\cdots \\
\cdots\end{array}$ & $\begin{array}{r}517 \\
6,584 \\
14 \\
-\end{array}$ & $\begin{array}{r}7 \cdot 3 \\
92 \cdot 5 \\
0.2 \\
-\end{array}$ & $\begin{array}{r}1,631 \\
5,465 \\
19 \\
\end{array}$ & $\begin{array}{r}22.9 \\
76 \cdot 8 \\
0.3 \\
-\end{array}$ & $\begin{array}{r}318 \\
1,331 \\
150 \\
5,316\end{array}$ & $\begin{array}{r}4 \cdot 5 \\
18 \cdot 7 \\
2 \cdot 1 \\
74 \cdot 7\end{array}$ \\
\hline
\end{tabular}

TABLE IV

REPORTED RESPIRATORY SYMPTOMS BY AREA

\begin{tabular}{|c|c|c|c|c|c|c|}
\hline \multirow{3}{*}{ Area } & \multicolumn{6}{|c|}{ Reported Symptoms } \\
\hline & \multicolumn{2}{|c|}{$\underset{\text { Cough }}{\text { Morning }}$} & \multicolumn{2}{|c|}{$\begin{array}{l}\text { Cough during } \\
\text { Day or Night }\end{array}$} & \multicolumn{2}{|c|}{$\begin{array}{l}\text { Cough lasting } \\
3 \text { months or } \\
\text { more }\end{array}$} \\
\hline & No. & $\%$ & No. & $\%$ & No. & $\%$ \\
\hline $\begin{array}{l}\text { Urban }(5,661) \\
\text { Rural }(\mathbf{1 , 4 5 4 )} \\
\end{array}$ & $\begin{array}{r}454 \\
63 \\
\end{array}$ & $\begin{array}{l}8 \cdot 0 \\
4 \cdot 3 \\
\end{array}$ & $\begin{array}{r}1,406 \\
225 \\
\end{array}$ & $\begin{array}{l}24 \cdot 8 \\
15 \cdot 5 \\
\end{array}$ & $\begin{array}{r}276 \\
42 \\
\end{array}$ & $\begin{array}{l}4.9 \\
2.9 \\
\end{array}$ \\
\hline \multirow[t]{2}{*}{ Total $(7,115)$} & 517 & $7 \cdot 3$ & 1,631 & $22 \cdot 9$ & 318 & $4 \cdot 5$ \\
\hline & \multicolumn{2}{|c|}{$x_{1}^{2}=22 \cdot 8 * * *$} & \multicolumn{2}{|c|}{$x_{1}^{2}=56 \cdot 9 * * *$} & \multicolumn{2}{|c|}{$x_{1}^{2}=10.2 * *$} \\
\hline
\end{tabular}

$x^{2}=* * *$ significant

significant difference in respiratory symptoms by location of school. Children attending schools in urban areas reported significantly more symptoms than those in rural areas (Table IV).

\section{SMOKING AND ResPIRATORY SyMPTOMS}

Smokers reported more respiratory symptoms than non-smokers, regardless of urban or rural location of school (Table V). No difference for any respiratory symptom was found between boys and girls in the same smoking groups or from similar areas. The anomalous figures for rural smokers may be due to the small numbers involved.

TABLE II

SMOKING HABIT BY AREA (URBAN/RURAL)

\begin{tabular}{|c|c|c|c|c|c|c|c|c|c|c|c|c|}
\hline \multirow{2}{*}{\multicolumn{2}{|c|}{ Area }} & & \multicolumn{2}{|c|}{ Smokers } & \multicolumn{2}{|c|}{$\begin{array}{c}\text { Experimental } \\
\text { Smokers }\end{array}$} & \multicolumn{2}{|c|}{ Non-Smokers } & \multicolumn{2}{|c|}{ Not Known } & \multicolumn{2}{|c|}{ Total } \\
\hline & & & No. & $\%$ & No. & $\%$ & No. & $\%$ & No. & $\%$ & No. & $\%$ \\
\hline Urban & .. & .. & 274 & $4 \cdot 8$ & 1,631 & $28 \cdot 8$ & 3,753 & $66 \cdot 3$ & 3 & 0.1 & 5,661 & 100 \\
\hline Rural & .. & $\ldots$ & 70 & $4 \cdot 8$ & 393 & $27 \cdot 2$ & 988 & $68 \cdot 0$ & 1 & 0.1 & 1,454 & 100 \\
\hline
\end{tabular}


TABLE V

REPORTED RESPIRATORY SYMPTOMS BY SEX, AREA, AND SMOKING

\begin{tabular}{|c|c|c|c|c|c|c|c|c|c|c|c|c|c|c|}
\hline & & \multicolumn{4}{|c|}{ Smoker } & \multicolumn{4}{|c|}{ Experimental Smoker } & \multicolumn{4}{|c|}{ Non-Smoker } & \multirow[b]{3}{*}{ Not Known } \\
\hline & & \multicolumn{2}{|c|}{ Urban } & \multicolumn{2}{|c|}{ Rural } & \multicolumn{2}{|c|}{ Urban } & \multicolumn{2}{|c|}{ Rural } & \multicolumn{2}{|c|}{ Urban } & \multicolumn{2}{|c|}{ Rural } & \\
\hline \multicolumn{2}{|c|}{ History of Cough } & No. & $\%$ & No. & $\%$ & No. & $\%$ & No. & $\%$ & No. & $\%$ & No. & $\%$ & \\
\hline $\begin{array}{l}\text { Cough a.m. } \\
\text { Cough day or } \\
\text { night } \\
\text { Cough } 3 \text { months }\end{array}$ & $\begin{array}{l}\text { Boys } \\
\text { Girls } \\
\text { Boys } \\
\text { Girls } \\
\text { Boys } \\
\text { Girls }\end{array}$ & $\begin{array}{l}43 \\
14 \\
96 \\
35 \\
36 \\
10\end{array}$ & $\begin{array}{l}21 \cdot 5 \\
18 \cdot 9 \\
48 \cdot 0 \\
47 \cdot 3 \\
18 \cdot 0 \\
13 \cdot 5\end{array}$ & $\begin{array}{r}3 \\
4 \\
17 \\
3 \\
3 \\
1\end{array}$ & $\begin{array}{r}5 \cdot 7 \\
23 \cdot 5 \\
32 \cdot 1 \\
17 \cdot 6 \\
5 \cdot 7 \\
5 \cdot 9\end{array}$ & $\begin{array}{r}107 \\
50 \\
304 \\
176 \\
47 \\
32\end{array}$ & $\begin{array}{r}10.3 \\
8.4 \\
29.4 \\
29.5 \\
4.5 \\
5.4\end{array}$ & $\begin{array}{r}19 \\
8 \\
55 \\
22 \\
15 \\
3\end{array}$ & $\begin{array}{r}7 \cdot 3 \\
5 \cdot 9 \\
21 \cdot 2 \\
16 \cdot 2 \\
5 \cdot 8 \\
2 \cdot 2\end{array}$ & $\begin{array}{r}102 \\
138 \\
336 \\
458 \\
69 \\
82\end{array}$ & $\begin{array}{r}6 \cdot 1 \\
6 \cdot 7 \\
20 \cdot 0 \\
22 \cdot 1 \\
4 \cdot 1 \\
4.0\end{array}$ & $\begin{array}{l}11 \\
18 \\
57 \\
71 \\
10 \\
10\end{array}$ & $\begin{array}{r}2 \cdot 7 \\
3.1 \\
13.9 \\
12.3 \\
2.4 \\
1.7\end{array}$ & \\
\hline Total .. & $\begin{array}{l}\text { Boys } \\
\text { Girls }\end{array}$ & $\begin{array}{r}200 \\
74\end{array}$ & & $\begin{array}{l}53 \\
17\end{array}$ & & \begin{tabular}{r|}
1,035 \\
596
\end{tabular} & & $\begin{array}{l}259 \\
136\end{array}$ & & $\begin{array}{l}1,678 \\
2,075\end{array}$ & & $\begin{array}{l}409 \\
579\end{array}$ & & $\begin{array}{l}2 \\
2\end{array}$ \\
\hline
\end{tabular}

For each of the respiratory symptoms considered, urban smokers reported the highest rate. Fortyeight per cent of these smokers reported day or night cough compared with $29 \%$ of experimental smokers and $21 \%$ of non-smokers. Among rural children, the corresponding figures were $29 \%, 19 \%$, and $13 \%$. A further analysis by a maximum likelihood regression technique (Naylor, 1964) showed that respiratory symptoms were significantly associated with the level of smoking and with location of school. There was no interaction between these two factors, which suggests that they affect respiratory symptoms independently. Children smoking more than one cigarette a day reported a higher proportion of symptoms than other smokers. But the number of children in this group was too small to allow conclusions to be drawn.

\section{LOCATION OF ScHOOL}

Reported respiratory symptoms were found to be associated independently with smoking and with urban/rural location of school. This area effect can

TABLE VI

MALE POPULATION AGED 15 YEARS AND OVER BY SOCIAL CLASS

(NON-MANUAL/MANUAL)

(A.C. Derbyshire excluding Chesterfield)

\begin{tabular}{|c|c|c|c|c|}
\hline \multirow[t]{2}{*}{ Type of Area } & \multicolumn{2}{|c|}{$\begin{array}{l}\text { Social Class } \\
\text { 1-3 Non-Manual }\end{array}$} & \multicolumn{2}{|c|}{$\begin{array}{l}\text { Social Class } \\
\text { 3-5 Manual }\end{array}$} \\
\hline & No. & $\%$ & No. & $\%$ \\
\hline $\begin{array}{l}\text { Urban } \\
\text { Derbyshire M.B.s and } \\
\text { Urban Districts (excluding } \\
\text { Chesterfield M.B.) } \\
\quad(108,970)\end{array}$ & 24,410 & $22 \cdot 4$ & 84,560 & $77 \cdot 6$ \\
\hline $\begin{array}{l}\text { Rural } \\
\text { Rural Districts (excluding } \\
\text { Chesterfield R.D.) } \\
(104,450)\end{array}$ & 31,340 & $30 \cdot 0$ & 73,110 & $70 \cdot 0$ \\
\hline
\end{tabular}

$x_{1}^{2}=159.4(P<0.001)$ Reference: General Register Office (1967). (County Report, Derby-
shire). be explained in a number of ways. The social class distribution is different in the two types of area (Table VI) and this may account for some of the differences in prevalence of respiratory symptoms. Variation in levels of air pollution is another possible explanation. No measures of air pollution were available for the rural areas of Derbyshire during the study period. However, in 1970, the average urban and rural pollution levels for a three-month summer period were recorded. This showed a mean rural smoke level of $31.26 \mu \mathrm{g} / \mathrm{m}^{3}$ compared with $64.4 \mu \mathrm{g} / \mathrm{m}^{3}$ for the urban areas. The rural sulphug dioxide was $62.5 \mu \mathrm{g} / \mathrm{m}^{3}$ compared with the urbat $95.9 \mu \mathrm{g} / \mathrm{m}^{3}$ (National Survey of Smoke and Sulphufi Dioxide, 1970-71).

\section{Discussion}

Our findings suggest that smoking is already a problem at primary school. One child in 20 of the study population was smoking and about one in three had experimented with cigarettes before leaving primary school. Boys reported smoking more frequently than girls and smoked more cigarettes. Children who smoked reported more respiratory symptoms and those attending schools in urban areas had significantly more symptoms than those in rural areas.

Since there have been no other large-scale 욱 prevalence studies of smoking in this age group, we cannot compare results. However, similar findings have been reported by Holland and his colleagues (Holland and Elliott, 1968; Holland et al., 1969 a $\sigma$ and b) for secondary schoolchildren in Kent. They $N$ suggested that smoking and area of residence were $\underset{\omega}{N}$ related to respiratory symptoms and that levels of $\bar{O}$ air pollution were important.

Confirmed habitual smoking and early lung damage are known to cause severe respiratory $\stackrel{?}{-}$ disease in later life (Royal College of Physicians, ,

$$
\overrightarrow{\mathrm{c}}
$$


$1962,1971)$. The implications of our findings therefore seem clear. Efforts must be made to persuade children at primary school not to start smoking.

\section{SUMmaRY}

This paper describes the first large-scale prevalence study of smoking by primary schoolchildren. Questionnaires on smoking and respiratory symptoms were completed by 7,115 final year primary schoolchildren (3,636 boys and 3,479 girls) in Derbyshire. Regular smoking was reported by $6.9 \%$ of boys and $2.6 \%$ of girls and a higher proportion of boys experimented with cigarettes. Boys also smoked more cigarettes. Smoking was associated with three reported respiratory symptoms and children who smoked more reported more symptoms. Children attending schools in urban areas had significantly more symptoms than those in rural areas. More effective measures to discourage smoking by primary schoolchildren are needed.

We wish to thank Professor W. W. Holland, Mrs. J. Waller, Miss I. Day, Mrs. S. Gilderdale, and Mr. J. M. Bland for their valuable help and advice in this study. The study would not have been possible without the cooperation of Mr. G. Fowler, Director of Education, Derbyshire, and his staff. Our thanks are also due to $\mathrm{Mr}$. S. G. Nicholas for help with the data preparation. This work was part of a dissertation for M.Sc. (Social Medicine) (B.R.B.) and is at present supported by an MRC Grant.

\section{REFERENCES}

Colley, J. R. T., and ReID, D. D. (1970). Urban and social origins of childhood bronchitis in England and Wales. Brit. med. J., 2, 213.

Douglas, J. W. B., and Waller, R. E. (1966). Air pollution and respiratory infection in children. Brit. $J$. prev. soc. Med., $20,1$.
E.D. (1606). "The copy of a letter written by E.D. Doctor of Physic to a gentleman by whom it was published" London 1606. Quoted in Edward Arber (Ed) The Essays of a Prentise, in the Divine Art of Poesie (1585) and A Counterblast to Tobacco (1604), p. 114. English Reprints (1895). Constable, London. General Register Office (1967). Sample Census 1966. County Report Derbyshire. H.M.S.O., London.

Holland, W. W., and Elliotr, A. (1968) Cigarette smoking, respiratory symptoms and anti-smoking propaganda. Lancet, $1,41$.

- Halil, T., Bennett, A. E., and Elliott, A. (1969a). Factors influencing the onset of chronic respiratory disease. Brit. med. J., 2, 205.

$\longrightarrow,-,-$, and,$-(1969 \mathrm{~b})$. Indications for measures to be taken in childhood to prevent chronic respiratory disease. Milbank mem. Fd Quart., 47, No. 3, Part 2, p. 215.

LunN, J. E., KNowelden, J., and Handyside, A. J. (1967). Patterns of respiratory illness in Sheffield infant schoolchildren. Brit. J. prev. soc. Med., 21, 7.

- - - , and RoE, J. W. (1970). Patterns of respiratory illness in Sheffield junior schoolchildren. Brit. J. prev. soc. Med., 24, 223.

Medical Research Council (1960). Standardized questionaries on respiratory symptoms. Brit. med. J., 2, 1665 .

(1967). Standardized questionary on respiratory symptoms. Brit. med. J., 1, 313.

National Survey of Smoke and Sulphur Dioxide (1970-71). Annual Tables. March 1970-April 1971. Department of Trade and Industry. Warren Spring Laboratory.

NAYLOR, A. F. (1964). Comparisons of regression constants fitted by maximum likelihood to four common transformations of binomial data. Ann. Hum. Genet., 27, 241.

Royal College of Physicians of London (1962). Smoking and Health. Pitman Medical, London.

(1971). Smoking and Health Now. Pitman Medical and Scientific, London. 